\title{
PROTAGONISMOS, MILITÂNCIAS E QUERELAS INSTRUCIONAIS NA TRINCHEIRA RELIGIOSA: COMBATES PELA ESCOLA CATÓLICA NA PARAHYBA DO NORTE (1894-1922)
}

\section{Ramsés Nunes e Silva'}

\begin{abstract}
A quem caberá liderar os moços? O mundo? Os não tementes a Deus? Conclamai servos católicos a guerra se aproxima de nosso torrão. Combatamos o indiferentismo! ${ }^{2}$
\end{abstract}

O editorial do principal jornal católico paraibano, que circulava na capital da exprovíncia em meados do Oitocentos, foi taxativo em sua recusa pelo fim da ingerência clerical nos meandros culturais, sociais e políticos cotidianos. Querelas manifestadas no Brasil a partir da Constituição de $1891^{3}$. Entre elas as instrucionais, balizadas pelo sistema republicano.

Aquele sistema político, recém-proclamado no Brasil, era adversário direto da Igreja, mesmo tendo se apresentado parte da intelectualidade católica, contemplada com a liberdade de culto. Manifestação política disposta pelo fim do regime de padroado. Destarte, rapidamente foram criadas outras estratégias de embate discursivo.

Naquele contexto, os aliados de véspera ao derrubarem a monarquia se voltaram para seus próprios interesses $e$ foram guiados por caminhos nem sempre convergentes. Militares e civis, advogados e coronéis da guarda nacional, lentes, jornalistas e empresários. Os clérigos nesse item, legitimados por seus tutores nos seminários, bispos e demais intelectuais, despontavam em novo métier combativo imantado àquele círculo societário.

Boa parte deles postulantes a papéis de protagonistas nas disputas apresentadas, à medida que decretos tornavam as fronteiras, ao menos no papel, entre o universo laico e confessional pouco firmes. Posições aparentemente definidas, mas que ainda não tinham lastro fixo dentro de qualquer tradição. Estas inclusive abertas à formação.

Segundo Carvalho ${ }^{4}$, a nação, tornada República, precisava de símbolos que a ratificassem, inclusive quanto ao trato com a tradição católica. Manifestação que é esclarecedora, posto que também contraditória, exatamente por não ser possível

\footnotetext{
${ }^{1}$ Historiador, Doutor em Educação pela Universidade Federal da Paraíba. Em 2015 realizou estágio pósdoutoral em História da Educação na Universidade do Minho, em Braga, Portugal. É Professor Adjunto do Curso de Arquivologia da Universidade Estadual da Paraíba, campus de João Pessoa. EMail: <ramsesnunes@gmail.com>.

${ }^{2}$ QUE SERÁ dos cristãos? A Imprensa, Cidade da Parahyba, n. 3, 2 mar. 1900.

${ }^{3}$ A Imprensa foi o periódico representativo da intelectualidade católica paraibana, fundado pelo bispo Dom Adauto Aurélio de Miranda Henriques, em 25 jul. 1897, para funcionar como órgão jornalístico oficial da diocese sob seu comando. Publicava artigos, resenhas e críticas de foro doutrinal.

${ }^{4}$ CARVALHO, José Murilo de. A formação das almas: o imaginário da República no Brasil. São Paulo: Companhia das Letras, 1991.
} 
entender dicotomias tão efetivas e imediatas entre as simbologias laica e confessional, por exemplo, nos espaços instrucionais espalhados pelas ex-províncias, embora tenha sido surpreendente para uma parte significativa da intelectualidade católica o conteúdo e a temática laicizante da constituinte de 1890, e do Decreto $\mathrm{n}^{\circ} 119$-A. Este último laicizou a instrução pública e contribuiu minimamente com a secularização da jovem sociedade republicana instalada 5 .

Esse aspecto conjuntural não escapou às estratégias criadas pela Sé romana para se fazer forte perante aqueles novos tempos. Afinal, foi junto a seus espaços de mando, entre eles colégios diocesanos e seminários, que se manifestaram tanto no Velho Mundo, quanto no Brasil, como aponta Azzi ${ }^{6}$, as mais diversas querelas teológicas, filosóficas e políticas. Entre elas, as que eram postulantes de uma educação marcadamente católica, frente ao cientificismo e laicismo, ambos dispositivos comuns à cultura republicana naqueles tempos da transição oitocentista, $e$ de vertigem modernizante, de acordo com Neves ${ }^{7}$.

Potencializava-se, afinal, uma verdadeira guerra de textos e posturas que circularam da Igreja romana para o Brasil, por ocasião das disputas ultramontanas, segundo Martina ${ }^{8}$, afirmação de uma disciplinarização do catolicismo, também fenômeno que rumava internamente rumo ao endurecimento no trato com temáticas modernizantes e, na percepção de Andrade ${ }^{9}$, afirmação e reforço na ortodoxia dos quadros eclesiásticos.

No bojo dos temas de debate se apresentou, ao menos no âmbito da legislação, a secularização da instrução e a transformação da educação religiosa em dispositivo facultativo. Este último fator, tema de embate nunca totalmente sanado no Brasil, mas, tão-somente, mediado no lastro das relações entre Estado e Igreja.

Havia, outrossim, por volta da última década do século XIX, tanto uma urgência em certo enrijecimento de posições quanto, ao mesmo tempo, visível tessitura normativa lançada sempre que adaptabilidades possíveis fossem executáveis. Era isso que propiciava interpretações complexas no tempo. A ideia mesma de progresso é

\footnotetext{
${ }^{5}$ A secularização, enquanto manifestação do âmbito do universo cristocêntrico, pode ser entendida a partir de uma extensa gama de interpretações historiográficas, de Max Weber a Peter Berguer. Neste artigo escolhemos conceber sua disposição como um recuo na simbologia providencialista em prol de uma mundanização das relações sociais, culturais e políticas. Aspectos que se intensificaram no Velho Mundo no final do século XIX e que permanecem como tema de reflexão sobre a sociedade contemporânea no tocante à relação entre o sagrado e o profano. A laicização, por seu lado, também enquanto manifestação social teria um caráter de ferramenta discursiva/ normativa, bem como instrumento das relações entre confissões religiosas, Estado e sociedade civil, a partir de princípios nos quais a neutralidade seria conduto regulador.

${ }^{6}$ AZZI, Riolando. História da Igreja no Brasil - terceira época: 1930-1964. Rio de Janeiro: Vozes, 2008, p. 52.

7 NEVES, Margarida de Souza. "Os cenários da República. O Brasil na virada do século XIX". In: DELGADO, Lucilia de Almeida Neves \& FERREIRA, Jorge (orgs.). O tempo do liberalismo excludente: da proclamação da República à Revolução de 30. Rio de Janeiro: Civilização Brasileira, 2003, p. 1956.

${ }^{8}$ MARTINA, Giacomo. História da Igreja, de Lutero aos nossos dias: Vol. III - A Era do Liberalismo. Tradução de Orlando Soares Moreira. São Paulo: Loyola, 1996.

${ }^{9}$ ANDRADE, Maristela Oliveira de. 500 Anos de catolicismos \& sincretismos no Brasil. João Pessoa: Ed. Universitária/ UFPB, 1999, p. 125-147.
} 
cristã e catholica, diria o edital de A Imprensa, por volta de $1897^{10}$. Ora, muitas lideranças católicas permaneceram nos cargos de lentes das escolas normais e liceus espalhados pelo país, mesmo quando proclamada a República, na Parahyba do Norte um dispositivo que facultava o funcionamento de inúmeras cadeiras isoladas na capital do estado e no interior.

Para a Igreja em seus trâmites diocesanos o significado era ainda mais complexo.

Ali e nos meandros sociais e culturais, em que pesem as disputas políticas e as mudanças na legislação, permanecia desejável o diálogo entre discursos que propiciavam a manutenção de alguma notoriedade ao catolicismo, mesmo quando este estava a serviço do civismo republicano. Segundo discursos correntes entre católicos, disposição possível desde que apresentados como interpretações chanceladas por Roma, para a nova ordem, notadamente, a partir de um universo confessional, como no edital de A Imprensa, de dezembro de 1897:

Um signal dos tempos é que apesar dos apregoados progressos da sciencias naturaes com seu methodo positivo, a sciencia religiosa conquista palmo a palmo largo terreno $e$ proclama seus domínios a inteligência e o coração da mocidade que ela dirige por meio de uma educação isenta de ódios e prevenções e de uma instrução que oferece como alvo ao homem aquela solene [...] nós diremos um signal dos tempos é que só a educação e instrucção religiosa preparar melhores dias. ${ }^{11}$

Para muitos católicos nos anos finais do Oitocentos valia tentar combater o laicismo com as armas normativas e legislativas do regime. Certamente os posicionamentos mais afirmativos e céticos, quanto a um diálogo entre posicionamentos, foram apresentados junto aos suportes doutrinários e políticos que circulavam entre os meios letrados, particularmente junto aos impressos de circulação diária, espalhados pelos estados da federação, tais como uma série de jornais, alguns oriundos ainda do Império, representativos dos mais diversos setores sociais, $e$ mesmo de livros onde intelectuais expunham seus textos sobre o novo século e suas querelas.

Chamam atenção querelas originárias das demandas que afetavam a tutela cultural cristã sobre a sociedade vigente, embora o país se mantivesse eminentemente cristocêntrico. Por todo o Brasil, jornalistas militaram por suas respectivas causas políticas no enfrentamento de universos; apresentavam-se, inclusive, como soldados nas praças-forte de certos periódicos e seus muitos discursos e simbologias dicotômicos, embora também fossem convergentes.

Semanários como A Imprensa, por exemplo, apresentavam defesa contraditória, tanto do civismo católico republicano quanto de uma intelectualidade que se considerava agredida por aquela sociedade cada vez menos confessional. Ironicamente, seu fundador, o bispo Dom Adauto Aurélio de Miranda Henriques

\footnotetext{
${ }^{10}$ LICÇÃO dos factos. A Imprensa, Cidade da Parahyba do Norte, n. 28, 5 dez. 1897.

${ }^{11}$ UM SIGNAL dos tempos. A Imprensa, Cidade da Parahyba do Norte, n. 29, 12 dez. 1897.
} 
(1890-1937), além de chefe político de duro posicionamento frente à secularização, também foi o principal articulador político entre as elites republicanas da Parahyba do Norte, nos anos iniciais do século XX, elites que nunca deixaram de convidá-lo para as inaugurações dos grupos escolares de currículo laico.

Sua chancela espiritual e política permaneceu intacta. Era, afinal, da natureza de uma secularização à brasileira, marcadamente híbrida se buscarmos especificidades da cultura e da sociedade da América do Sul, como nos alerta Canclini ${ }^{12}$, potencialmente aliada, sempre que possível, aos meandros do poder manifestados no civismo ufanista, mas que conclamava à combatividade entre modelos culturais $e$ societários católicos.

De qualquer forma, é importante lembrar que o universo cultural católico, de forma coesa e orgânica, especialmente o romanizado, já desde o início da segunda metade do século XIX, apresentava-se em ebulição, principalmente em termos de discursos contrários a outros credos, práticas e sociabilidades que não fossem os católicos.

Afinal, todo um aparato normativo que tutelava, via catolicismo, as manifestações culturais, políticas e sociais, havia séculos na sociedade brasileira e europeia, aparentava se esvair naquilo que Catroga ${ }^{13}$ infere como sendo parte de uma religião civil. Espécie de manifestação interpretativa das simbologias liberais e republicanas a serviço da dessacralização das sociedades e de símbolos especificamente laicizantes. Alguns deles eram abertamente positivistas, como é o caso de muitas das simbologias que se mantiveram em combate acirrado no Brasil, recém-proclamada a República, junto à ratificação de datas civis no calendário nacional em detrimento inclusive daquelas datas de lastro religioso, e da secularização dos cemitérios, por exemplo.

Todo um aparato estratégico, para atender aos envolvidos com o novo sistema político, foi preterido. Foram aprofundadas as estratégias de arregimentação da sociedade, a ser educada numa cultura escolar católica, e dentro daquela espécie de postulado normativo, assentado nas mais diversas interpretações legitimistas do catolicismo ensinado, a ser apreendido e doutrinado.

As instituições da República, muitas delas escolares e instrucionais, formaram cabedais importantes na trama de alargamento das novas raízes simbólicas rivais do catolicismo, a saber, o positivismo e o liberalismo, os dois preceitos filosóficos, alvos preferenciais das querelas na primeira luz do Oitocentos. Basta observar os temas recorrentes entre textos publicados em língua portuguesa, ao findar o século XIX, e lidos avidamente por seminaristas e leigos.

Ora, segundo Miceli ${ }^{14}$ a resistência dos intelectuais clericais em meados do Oitocentos, e nas décadas posteriores, colocou em cheque o que acreditavam ser a necessidade de permanência da Igreja nos meandros das relações de poder. Aquela manifestação tomou ares de tema recorrente, a partir dos muitos discursos elaborados por uma profusa e complexa malha de segmentos dos quadros intelectuais da Santa

\footnotetext{
${ }^{12}$ CANCLINI, Néstor Garcia. Culturas híbridas: estratégias para entrar e sair da modernidade. Tradução de Eloisa Pezza Cintrão e Ana Regina Lessa. São Paulo: EDUSP, 1997.

13 CATROGA, Fernando. Entre deuses e césares: secularizacão, laicidade e religião civil - uma perspectiva histórica. Coimbra: Edições Almedina, 2010.

${ }^{14}$ MICELI, Sérgio. A elite eclesiástica brasileira, 1890-1930. Rio de Janeiro: Bertrand, 2009.
} 
Sé, notadamente da juventude estudantil encerrada nos seminários, espalhados pelo vasto universo católico brasileiro.

Nesse item, o teor dos ataques aos dogmas, segundo aquele universo social engajado, vinha de certa filosofia positivista; da ciência evolucionista; e mesmo de setores intelectuais maçons, anarquistas e socialistas. Por todo o mundo católico, para uma ala endurecida da Igreja, encetada nas disposições do Vaticano I, estava em curso uma espécie de campanha.

Uma significativa gama de postulados argumentava, aliás, ser urgente a reocupação de importantes setores sociais e políticos nos quais a Igreja atuava, e dos quais se considerava expurgada. No transcurso de alguns anos, toda uma conjuntura interna e externa da Igreja oitocentista potencializou nova estratégia. É o que destaca Martina sobre os objetivos dos pontificados de finais do século XIX:

Realizar contra o racionalismo teórico e prático do século XIX o que o tridentino tinha realizado contra o protestantismo do século XVI, ou seja reafirmar numa sociedade que depois da revolução francesa era levada a negar no mínimo muitos valores sobrenaturais e a aceitar sem muita dificuldade uma política laicista e secularizante as verdades fundamentais do cristianismo e os deveres de um católico mesmo numa sociedade cada vez mais laica. ${ }^{15}$

Uma verdadeira frente comum de protagonismos adversários se apresentava às claras, na imprensa mundial e nos interstícios dos sistemas de governo, nos quais o modelo republicano era o principal norte. Não seria à toa que uma série de postulados, entre eles os que se contrapunham à Igreja Católica frente à secularização de costumes, à laicização da instrução, ao cientificismo e à tutela dos fiéis pelo Estado, de forma cada vez mais contundente, nos círculos intelectuais europeus e sulamericanos.

Não obstante, foram diversos os combates discursivos publicados entre o final do século XIX e início do século XX, a admoestarem os fiéis frente ao mundo profano, como infere Catroga ${ }^{16}$, ao observar a dinâmica do conflito filosófico e científico instaurado.

Um mundo de embates se fazia antever, passados os primeiros tempos revolucionários na França e demais nações em situação de mudança paradigmática, ou de ajustamento às novas demandas científico-culturais, inclusive junto à Igreja Católica brasileira, entre o chamado mundo sagrado e o profano e demais simbologias da República e da cultura católica. Toda uma perspectiva de substituição de certa sacralização social e cotidiana por um mundo profano de cunho civil era real $e$ acabou por se manifestar factível, embora abaixo da Linha do Equador se mostrasse particular e como gosta de enfatizar Canclini ${ }^{17}$, hibridizada em sua dinâmica cultural.

\footnotetext{
${ }^{15}$ MARTINA, História da Igreja..., p. 34-40.

${ }^{16}$ CATROGA, Entre deuses..., 2010.

${ }^{17}$ CANCLINI, Culturas hibridas..., p. 283-350.
} 
Aliás o mundo intelectual do Oitocentos produziu uma espécie de cartilha de protagonismos que se fez interpretar de forma muito mais enfática, à medida que se delimitavam, por exemplo, fronteiras entre a escola pública laica e a privada, de cunho confessional. Este tema era base de muitos dos embates propiciados pelas correntes discursivas da época, e nas quais se lançou toda uma geração de intelectuais, das mais diversas correntes de pensamento, de ultramontanos a deístas, de seguidores de Spencer a ferrenhos defensores da escola confessional. Junto a todos eles: apaziguadores e intérpretes clericais da modernidade.

Destarte, desde uma gama de documentos oficiais produzidos pela Sé romana e seus respectivos pontífices, na forma de Cartas Encíclicas, até o que parecia ser um projeto de expansão das escolas diocesanas na América, convergiam projetos em comum, em que a escola católica $e$ as práticas instrucionais confessionais eram importantes bases doutrinais, especialmente na perspectiva de instrumentos chancelados pela romanização.

Foram apresentadas sucessivamente pelos católicos, é importante destacar, leituras daquele mundo no tempo, visto como época especialmente em transição, acelerada e disforme. Assim como também aponta $\mathrm{Neves}^{18}$, mundo vertiginoso em suas descontinuidades, embora possamos pensar as contradições nos espaços intelectuais brasileiros, a partir de suas rupturas e permanências, frente àquele oceano de transformações, nas quais confessionalidade e providencialismo se imbricavam na "instrução moderna" de lastro católico.

Certamente o cabedal de significados potencializados pela chamada modernidade para aquele mundo, cada vez mais distanciado da confessionalidade e do regalismo, parecia afetar seriamente o monopólio eclesiástico, ainda mais no que parecia ser uma série de instâncias cimentadas nas relações de poder da Igreja, frente ao mundo contemporâneo, junto a seus respectivos sistemas de governo, fossem monárquicos ou republicanos.

Essa, devemos lembrar, era uma temática em que se lançavam os setores sociais letrados na Europa e no Brasil, muitos deles responsáveis pela considerável produção textual, com extenso repertório de querelas discursivas. De parte da cúpula romana, documentos como as encíclicas Quanta Cura, Sylabus e Rerum Novarum se tornaram exemplos da resistência à secularização e na qual seus autores, Leão XIII e Pio IX, respectivamente, mostraram-se adversários do avanço mundano.

Os respectivos líderes eram diretos em seus postulados: cabia à Igreja discernir e regular, encaminhar e doutrinar, formar e salvar a sociedade de finais do século XIX, considerada em desalinho. Tais documentos acabaram por ter impacto direto sobre as instâncias clericais, dentre elas as escolares, bem como junto ao laicato católico, conclamado a ajudar no embate de modelos instrucionais.

Ora, aqueles pontífices acabaram, sucessivamente, por reafirmar o Concílio Vaticano I em sua essência: solidificar a cristianização da sociedade moderna, haja vista a intricada rede de instituições defensoras do modelo católico de sociedade no Brasil de finais do Oitocentos, entre as quais, congregações dedicadas à instrução, reforçadas e expandidas, todas fixadas na linha de frente das querelas jornalísticas no último quartel do século XIX.

${ }^{18}$ NEVES, “Os cenários...”, p. 19-56. 
No tocante às estratégias advindas do Ultramontanismo, este último como manifestação mais ou menos coesa, entre intelectuais europeus, de negação das práticas e manifestações religiosas não católicas, estava a expansão de um modelo eclesial centralista, arregimentação na qual a figura do papa e um arrefecimento do controle deste junto à sociedade eram a peça-chave.

No Brasil, em menos de 20 anos após a promulgação da Constituição republicana de 1891, as demandas por um catolicismo militante já alcançavam segmentos sociais entre profissionais liberais, seminaristas, jornalistas leigos e lideranças eclesiásticas numa intensidade que só aumentou.

Os principais suportes impressos católicos espalhados pelo mundo, inclusive no Brasil, acabaram por repercutir longamente tais querelas, fosse pela tradução sistemática das encíclicas nos jornais curiais, desde a década de 1870, ou pela continuidade dos embates ainda nas décadas posteriores. Nessa esfera estava o apoio circunstancial de padres, bispos e cardeais a uma maior concentração de esforços combativos. Esforços esses, no tocante ao avanço da secularização junto a colégios, associações, ordens, congregações $e$ junto ao laicato. Manifestação observável no trânsito das ideias do cientificismo oitocentista, dos ambientes acadêmicos para a sala de aula e que tornou a Igreja, ao findar o século, um vetor de reações às mudanças no tocante à instrução, fosse para adaptá-las ou miná-las. Uma manifestação coesa que se espalhou pelos estados da jovem República, a tencionar uma resposta do centralismo romano nos assuntos pertinentes à instrução. Gradualmente aquele tema foi apresentado como espécie de carro-chefe na arregimentação intelectual de padres, leigos e católicos de uma forma geral.

Em contrapartida, matrizes instrucionais tais como o protestantismo ${ }^{19}$, por exemplo, e a esfera laicizante de iniciativa estatal, viraram alvo dos debates realizados na Primeira República, dos púlpitos das igrejas aos salóes do nascente setor social urbano brasileiro.

Nos estados da federação republicana, entre eles a Parahyba do Norte, fenômeno que não foi circunscrito ao universo de claustro ou de confinamento escolar, mas a uma seara combativa, embora imbricada naquela perspectiva indicada por Catroga como fenômeno vivenciado numa sociedade entre deuses e césares ${ }^{20}$. Aspecto este visível dos dois lados do Atlântico, na manutenção de um providencialismo cotidiano - a afetar tudo e todos - mas também como numa secularização cristalizada junto a suportes, práticas e instituições escolares. Escopo de uma fixidez mais identificável na Europa, com nítida faceta dicotômica, eminentemente contraditória nos meandros culturais da Parahyba do Norte, não sem convergência de simbologias $e$ representações dos universos, segundo Silva ${ }^{21}$, que foram/são, de toda forma, rivais nos espaços instrucionais.

${ }^{19}$ HILSDORF, Maria Lúcia S. História da Educação brasileira: leituras. São Paulo: Tomson Learning, 2006.

${ }^{20}$ CATROGA, Entre deuses..., p. 70.

${ }^{21}$ SILVA, Ramsés Nunes e. Signal dos tempos: modernidade, secularização e laicização na Instrução Pública da Parahyba do Norte (1867-1902). Dissertação (Mestrado em Educação). Universidade Federal da Paraíba. João Pessoa, 2006. 


\section{A reestruturação das arquidioceses no Brasil e os combates pela escola confessional na Parahyba do Norte}

Em meados do século XIX foi marcante a conjuntura de reestruturação das arquidioceses brasileiras com a criação/ desmembramento das províncias clericais em novos núcleos de poder, conjuntura que configurou, de acordo com Ferreira ${ }^{22}$, intenção de redistribuição na balança das relações político-clericais, em cada região. Representou parte de uma estratégia de expansão doutrinária, reconfiguração administrativa, como também reforço, no âmbito da influência social da Igreja, a partir de setores intelectuais romanizados, como afirma Miceli ${ }^{23}$ e $\mathrm{Dias}^{24}$, parte considerável dessa influência apresentada na esfera da instrução confessional, segundo Silva ${ }^{25}$.

Uma verdadeira marcha expansionista diocesana se apresentou em curso. Fenômeno que Miceli ${ }^{26}$ chama de estadualização diocesana, quando da emergência da temática educacional como um dos instrumentais normativos mais recorrentes, também forma de delegar e distribuir poderes sob o escrutínio das lideranças bispais. Um exemplo é o que ocorre para a fundação da arquidiocese paraibana. Podemos lembrar que arquidioceses como as de Pernambuco exerciam influência direta sobre quase todas as ex-províncias do Império. Ainda segundo Ferreira: [...] A Igreja procurava se reciclar institucionalmente [...] a partir da renovação de sua base de sustentação financeira, da ampliação da sua influência no sistema educacional, além de outras estratégias de ação ${ }^{27}$.

Pernambuco, diga-se, absorvia e instruía o magistério eclesiástico do Norte responsável pela preparação de centenas de jovens, na condição de seminaristas. Também aquele estado e arquidiocese eram respectivamente fecundos, como seleiros de formação intelectual burguesa e eclesiástica, segundo Alves ${ }^{28}$, fenômeno social fomentado nos bancos do Seminário Episcopal de Nossa Senhora da Graça de Olinda.

Era dali, por exemplo, que partiam muitos jovens estudantes-padres para o Pontifício Colégio Pio Latino-Americano em Roma, numa espécie de estágio intelectual, donde se dirigiam para formação. Outrossim, voltavam como doutores em direito canônico e filosofia, titulação defendida na Pontifícia Universidade Gregoriana. Aspecto somado ao retorno daqueles eclesiásticos para o Nordeste, distribuição de suas atividades pelas diversas paróquias, produção jornalística junto a redações, docência nos colégios (inclusive públicos) e participação daqueles padres junto a

${ }^{22}$ FERREIRA, Lúcia de Fátima Guerra. Igreja e Romanização: a implantação da Diocese da Paraíba (1894-1910). Tese (Doutorado em História Social). Universidade de São Paulo. São Paulo, 1994.

${ }^{23}$ MICELI, A elite eclesiástica..., 2009.

${ }^{24}$ DIAS, Roberto Barros. Deus e a Pátria: Igreja e Estado no processo de Romanização na Paraíba (18941930). 2008. Dissertação (Mestrado em História). Universidade Federal da Paraíba. João Pessoa, 2008.

${ }^{25}$ SILVA, Signal dos tempos..., p. 57.

${ }^{26}$ MICELI, A elite eclesiástica...

${ }^{27}$ FERREIRA, Igreja e Romanização..., p. 34.

${ }^{28}$ ALVES, Gilberto Luiz. O pensamento burguês no Seminário de Olinda (1800-1836). Campo Grande: Editora UFMS; Campinas: Autores Associados, 2001. 
associações e partidos católicos. Condições estas que se manifestaram nos estados circunvizinhos, inclusive na Parahyba do Norte.

Disposição recorrente ao longo do século XIX até a reestruturação do Seminário Diocesano da Paraíba, como parte das ações posteriores à fundação da nova diocese, ocorrida de acordo com Ferreira ${ }^{29}$, pela benfeitoria do papa Leão XIII (1878-1903), em 27 de abril de 1892. Outra dimensão política da Igreja para as novas dioceses acabou apresentada como estratégia afirmativa. Segundo Silva ${ }^{30}$ e Kulesza ${ }^{31}$, assim que eram formados/ ordenados, os clérigos passavam a atuar na patronage, no fomento e arregimentação política, catequética e instrucional junto a paróquias, congregações leigas, associações pias e administrações diocesanas.

Alguns daqueles clérigos eram intercessores ou intermediários entre as dioceses $e$ uma série de ordens religiosas dedicadas à instrução que aportaram no Brasil em Pernambuco e na Parahyba do Norte. Muitas daquelas ordens atuaram, fosse coincidência ou não, no nicho sociocultural dos desmembramentos e reajustes diocesanos, entre o final do século $\mathrm{XIX} e$ as primeiras décadas do século $\mathrm{XX}$, conforme Silva \& Santos ${ }^{32}$. Entre elas, por exemplo: Damas do Coração Eucarístico (França, 1895), Irmãs da Sagrada Família (França, 1906), Congregação das irmãs Doroteias (Itália, 1919), Irmandade marista (França, 1926), Damas da Instrução Cristã (Bélgica, 1932), Irmãs Franciscanas de Dillingen (Alemanha, 1939), Padres Franciscanos de Dillingen (Alemanha, 1939), Irmãs de Nossa Senhora de Lourdes (1940).

Ora, a escolha de uma liderança como o bispo Dom Adauto Aurélio de Miranda Henriques pela Sé romana, para liderar uma diocese como a da Parahyba do Norte, desmembrada de Pernambuco, pode ser percebida como sintomática.

Aquele arcabouço social e cultural, incutido em sua formação, que se manifestou por todo o mundo católico e nos estados da jovem República, dentro da esfera de embate intelectual, fez jus a um contundente esforço orgânico, dispensado localmente para se assenhorar dos interstícios nas relações de poder. Certamente muitos nos quais esteve a educação como alavanca, ordenada pelo bispo na tomada de espaço que se avizinhou. Foi bem esse o esforço da Sé romana pela projeção de sucessivas discussões, ao longo das primeiras décadas do século XX, pela hegemonia eclesiástica ameaçada.

As ações de bispos na esfera nacional, tais como Dom Sebastião Leme, ou intelectuais como Carlos de Laet, Felício dos Santos, Júlio Maria, Alceu Amoroso Lima, Leonel Franca, eram exemplo de tais querelas. O primeiro a assinar a Carta Pastoral de 1916, e os demais responsáveis por conclamarem nas décadas seguintes,

${ }^{29}$ FERREIRA, Igreja e Romanização..., p. 58.

${ }^{30}$ SILVA, Ramsés Nunes e. Soldado de Cristo: Odilon Alves Pedrosa e as trincheiras instrucionais em Pernambuco e na Paraíba (1916-1950). Campina Grande: EDUEPB, 2017.

${ }^{31}$ KULESZA, Andrej Wojciech. "Os Seminários como locais de formação Docente". In: CARDOSO, Carlos de Amorim \& KULESZA, Andrej Wojciech (orgs.). A Escola e a Igreja nas ruas da cidade. João Pessoa: Ed. Universitária/ UFPB, 2010.

32 SILVA, Ramsés Nunes e \& SANTOS, Tatiana de Medeiros. "Tessituras da instrução confessional inquirições acerca da educação cristocêntrica na Parahyba do Norte (1890-1937)”. In: CURY, Cláudia Engler \& PINHEIRO, Antonio Carlos Ferreira (orgs.). Histórias da Educação na Paraíba: rememorar e comemorar. João Pessoa: Ed. Universitária/ UFPB, 2012, p. 77-87. 
clérigos e sociedade civil por todo o Brasil, a resistirem às seduções do mundo profano, o que exigiu segundo argumentaram, por anos a fio, a necessidade de um sólido corpo de seguidores e fomentadores ${ }^{33}$.

$\mathrm{Na}$ Parahyba do Norte não seria diferente. Muitos textos acabaram por circular localmente, mesmo que fragmentados, nas páginas de seu principal periódico católico: A Imprensa. Todos eles chancelados pelo principal articulista da combatividade local: o bispo metropolitano. A questão do protagonismo da Igreja no tocante à escola cristã, frente à escola livre ou laica, já era mundial. Na Parahyba do Norte tomava corpo e se distendia.

Não seria à toa, em seguida, a entronização, o esforço por parte de Dom Adauto para dar vasão às já citadas estratégias de expansão, e modelagem das aspirações católicas ao modelo curial. Especialmente num processo onde as relações de poder, constituídas na esfera eclesiástica paraibana, alinharam-se às oligarquias alvaristas, venancistas e epitacistas ${ }^{34}$. Todas elas dentro da lógica do mandonismo da Primeira República a cotejarem favorecimentos, personalismos e ajustamentos às demandas dos projetos instrucionais do estado. Somada a essa dimensão, podemos observar que na Parahyba do Norte a influência clerical não tinha sido fragmentada, pois acabava por funcionar como forte instrumento cultural, especialmente naquele interstício de relações socioculturais. Aliás, não eram poucos os padres que se mantinham como lentes, contratados pelo estado. Ao mesmo tempo, a instância política que deveria se contrapor àquele estado de coisas, e mesmo setores sociais das elites bacharelescas, não elegiam a categoria eclesiástica como inimiga imediata.

Afinal, naquela esfera, mesmo o republicanismo paraibano, no qual deveria operar o positivismo, não era, segundo Rodrigues ${ }^{35}$, de todo firme, pelo menos nos primeiros suspiros da República, sendo pouco ativo, tardio, dominado por uma apatia até depois da proclamação, aspecto que pode ter sido observado como propício para a Cúria Metropolitana ocupar ou manter sua influência.

Dom Adauto, por seu turno, era exatamente o protótipo de toda uma geração de intelectuais que tiveram sua formação fincada exatamente no eixo Olinda-Roma. Ele mesmo ex-aluno do Pontifício Colégio Pio Latino-Americano, e da Pontifícia Universidade Gregoriana, na capital italiana. Fortemente centrado na leitura ipsis literis dos ditames papais, coube a Dom Adauto, um filho de proprietários rurais de Areia, no Brejo paraibano, uma atitude reguladora, hierarquizante e centralista na nova diocese, como nos aponta Kulesza ${ }^{36}$, inclusive, criando em torno de si um corpo de colaboradores, entre seminaristas, padres-lentes, professores leigos, jornalistas, médicos e juízes. Assim como uma série de eventos internos, donde partia um corolário de dispositivos discursivos, entre eles, retiros campesinos semestrais, onde os clérigos se colocavam sob a disciplinarização do bispo.

\footnotetext{
${ }^{33}$ VILAÇA, Antonio Carlos. O pensamento católico no Brasil. Rio de Janeiro: Civilização Brasileira, 2006.

${ }^{34}$ Designações nominais e historiográficas para as lideranças que se alternaram no poder do estado nas duas primeiras décadas do século XX: Álvaro Machado, Venâncio Neiva e Epitácio Pessoa, respectivamente.

35 RODRIGUES, Inês Caminha. A gangorra do poder (Paraíba, 1889-1930). João Pessoa: Ed. Universitária/ UFPB, 1989, p. 23.

${ }^{36}$ KULESZA, "Os seminários..., p. 127.
} 
Logo, uma série de disposições normativas, ações pastorais $e$ instrumentais disciplinadores da catolicidade se fizeram manifestar. Da fundação do jornal $A$ Imprensa, passando pelo fomento a escolas confessionais, como o Ginásio Diocesano Pio X, até a publicação de cartas pastorais ao longo de seu longo episcopado ${ }^{37}$. Este último instrumento episcopal, atentamente construído no sentido de publicitar intensões: era a Igreja $e$ a diocese, chamadas ao dever de combate à secularização de costumes. Na carta inaugural de saudação aos fiéis, datada de 1894, o líder local da Igreja especificava:

[...] Se a obra de deus nunca deixa de realizar-se, ainda quando tenha por teatro a idolatria, a barbárie indômita, o mais completo indiferentismo religioso $e$ o maior esquecimento da auctoridade divina, quantos motivos de esperança, não experimentará quem como nós tem assignalado por tarefa a conservação, o incremento $e$ aperfeiçoamento de um rebanho tão felizmente disposto $[\ldots]]^{38}$

Do referido tema do indiferentismo religioso sua reflexão aponta para outras searas. Dentre elas a autoridade clerical, a instrução católica e as estratégias dos líderes locais frente à modernidade, que queria derrotada, se possível, com as próprias armas que a mesma havia construído:

[...] A época actual exige ainda mais. Com efeito a defesa da fé catholica que deve ser o empenho principal dos sacerdotes é tão necessária em nossos dias reclama a uma instrucção, já $\underline{\text { não }}$ comum $\underline{e}$ medíocre, sinão profunda $\underline{e}$ variada: $\underline{u m a}$ instrucção que abrace não só as ciências sagradas, sinão também as ciências philosophicas e que seja enriquecida do

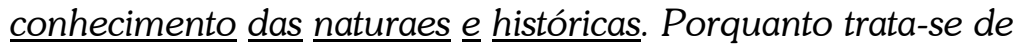
destruir erros numerosíssimos que offendem a todos os princípios da doutrina cristã e muitíssimas vezes é mister lutar

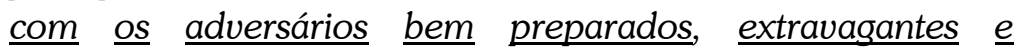
contumazes na discusssão e que com uma perfídia astúcia procurarão aproveitar-se de argumentos tirados de todos os ramos scientíficos $\left[\ldots . . .{ }^{39}\right.$

As estratégias do lugar da resistência contra o universo não católico, no qual se acharam expostos os fiéis paraibanos, naquele início de século, foi tema recorrente

\footnotetext{
${ }^{37}$ Um dos mais ativos e profícuos episcopados no âmbito da produção intelectual e militância clerical. Iniciado em 1892 foi encerrado apenas em 1937, por ocasião do falecimento do bispo, na já então renomeada cidade de João Pessoa.

${ }^{38}$ HENRIQUES, Dom Adauto de Miranda. Carta Pastoral de Saudação aos Fiéis. Cidade da Parahyba, 1894, p. 7.

${ }^{39}$ HENRIQUES, Carta Pastoral..., p. 8, grifos nossos.
} 
entre os intelectuais católicos incomodados pelo modelo societário secular. Todavia, desde o primeiro momento se fizeram articular junto a Dom Adauto possibilidades de barganhas, oficializações $e$ subvenções no qual se apresentaram o personalismo $e$ alianças, manobradas por intelectuais católicos, sempre dentro das fronteiras da legislação republicana $e$ instrucional.

Dali, o bispo Dom Adauto não se deixaria recuar. Entre suas projeções, importava tecer estratégias cotidianas que conduzissem certa tradição a uma cultura que, embora pudesse como álibi aparentar estar dentro dos ditames modernos, devia centrar-se na solidez dogmática. Em nova carta lançou proposta centrada na autoridade clerical, especialmente, como dispositivo normativo e instrumentalidade reguladora da liberdade de consciência. Dois temas carros-chefe, em termos de objetivos a serem superados:

[...] qual é falta de respeito a autoridade, si não formos della isentos [...] Logo a autonomia, a liberdade de consciencia, $\underline{\mathrm{o}}$ direito do livre pensamento em matéria de religião ou o indifferentismo religioso. [...] são erros injuriosissimos a Deus que só pode ser honrado com a verdade $e$ a virtude, $e$ funestissimos ao homem e a sociedade que pelo lume natural da razão deve conhecer a distancia infinita da verdade e do erro, da virtude e do vício ${ }^{40}$.

Seu trabalho, assim como o de uma considerável gama de intelectuais locais se debruçou de forma efetiva, entre outras temáticas do métier ultramontano, na interpretação da instrução como fator catalizador da moral cristã. Ficou célebre localmente nos círculos de debate o artigo não assinado ainda no século XIX, publicado em 1898, mas que estava válido no fim da década de 1910, já no século XX: A Igreja é uma escola ${ }^{41}$.

Foi esse o slogan que ratificou com estratégias sucintas aquilo que a carta assinada por Dom Leme em 1916 sancionou: era na busca por um engajamento um dos principais dispositivos de recristianização da sociedade, no qual estavam atuando clérigos e leigos a serviço de Roma e dos mandatos pontifícios. Na capital da Parahyba do Norte padres como Valfredo dos Santos Leal (1855-1942), ordenados em Roma, por exemplo, levaram às últimas consequências os ditames estratégicos romanos, com a ocupação de cargos públicos, tais como: deputado constituinte estadual (1892); deputado federal (1901); vice-presidente do estado da Parahyba do Norte em dois momentos (1893-1894 e 1904-1905). Nesse último ano, assumiu o

${ }^{40}$ HENRIQUES, Dom Adauto de Miranda. O sacerdócio e o Seminário diocesano. Cidade da Parahyba do Norte, 1897, p. 12, grifos nossos.

${ }^{41}$ HENRIQUES, Dom Adauto de Miranda. "A Igreja é uma escola". A Imprensa, Cidade da Parahyba do Norte, 10 jul. 1898, p. 3. Uma média de onze artigos publicados no jornal A Imprensa, dedicaram-se ainda nos últimos anos do século XIX, a denunciar a necessidade de endurecimento: A humanidade educada (3 jul. 1898); A Igreja é uma escola (10 jul. 1898); Escola nocturna (10 jul. 1898); A instrucção (19 mar. 1899); O ensino (7 jul. 1899); Escolas parochiais (3 ago. 1899); A educação cristã nas famílias (8 nov. 1899); A liberdade de ensino (28 jan. 1900); O ensino da doutrina crista (28 jan. 1900); A liberdade de ensino II (04 fev. 1900); Para ensinar (fev. 1900). 
cargo de governador do estado, a partir da renúncia de Álvaro Lopes Machado. Em 1908 foi eleito senador.

Dom Adauto à época preteriu e estimulou uma série de campanhas nas quais a laicidade era contestada no espaço escolar. Também o ensino religioso, as escolas católicas e os padres e leigos eram considerados legítimos herdeiros de uma escola cívica e republicana que, moderna, sem abandonar Deus, conseguiria tornar possível a evolução social e cultural. Esta, é importante lembrar, desde que guiada por agentes clericais. Agentes clericais esses aptos a conseguir realizar uma leitura das demandas modernas, em benefício da Igreja ${ }^{42}$.

De qualquer forma, o modelo docente-estudantil que se queria afirmar, neste caso o clerical, preconizado por Dom Adauto, foi duplamente vivenciado na Parahyba do Norte: na montagem nuclear do Seminário Diocesano e no incentivo à fundação de escolas católicas dentro do que previa a carta de intenções do bispo, ou da própria Igreja Católica brasileira.

O Seminário Diocesano, localizado em João Pessoa, mais particularmente nas dependências do Convento de Santo Antônio, rapidamente funcionou como uma esfera de vetor local reforçando a base doutrinal-formativa pernambucana, na qual bebeu o próprio bispo, e os lentes nos colégios confessionais, sobretudo na formação de futuros soldados eclesiásticos, prontos para o enfrentamento na guerra de modelos societários. A experiência de fomento estudantil eclesial, vivenciada em Pernambuco, serviu de matriz satisfatória para Dom Adauto.

Ali, no Seminário Diocesano, acolheu e submeteu seus alunos a um discurso consensual, que era encetado no combate e na diplomacia como pertencentes ao mesmo universo. Na escola se daria, portanto, a retomada de espaços nos quais o clero era partícipe importante. Mas não só. Uma intricada conjuntura de manifestações daquele postulado, de que era na escola cristã em que estava a salvação da juventude, frente à secularização, se manifestaria para servir de lastro às querelas pontuais: instrução cívica, patronage clerical, predomínio das escolas confessionais romanizadas, formação de associações católicas, entre outras.

Assim, a capital da Parahyba do Norte, entre os anos da transição entre o século $\mathrm{XIX}$ e XX, tornou-se um verdadeiro seleiro de intelectuais engajados na marcante disputa entre modelos socioculturais. Os veículos impressos locais se tornaram, inclusive, ano a ano, espaços de debate sobre temas como a ingerência normativa das escolas.

Dali também se abateu a aparente iminência de transformações refletidas na instrução, entre as quais: feminização do magistério, educação infantil, reformas curriculares e reformas na legislação escolar, temas recorrentes e que atravessaram as décadas seguintes.

No tocante às mudanças significativas, que se projetavam pelo/no sistema republicano, algumas acabaram insuflando opiniões dos setores sociais católicos, sequiosos de se colocarem novamente em evidência ou, quando não, nos casos de estados como o da Parahyba do Norte, realizarem a manutenção de relações onde a presença clerical era desejada, naquilo que o Estado localmente não se esforçava por realizar: um apartamento total e irrestrito da presença clerical na instrução.

${ }^{42}$ HENRIQUES, O sacerdócio e o Seminário..., p. 15.

SAECULUM - Revista de História [36]; João Pessoa, jan./jun. 2017. 
Basta observar o quadro de lentes ou deputados com qualificação na condição de melhores aliados das gestões pública e privada. Aspecto manifestado na instrução pública que, diga-se de passagem, funcionava na Parahyba do Norte com sérios entraves, entre eles, a estrutura ainda do Império, marcada pelas chamadas cadeiras isoladas. Um sistema que diluía as práticas educacionais pela insipiente formação dos lentes responsáveis, raro uso de compêndios, métodos de instrução adotados $e$ funcionamento irregular ao sabor das administrações, como especifica Pinheiro ${ }^{43}$.

A proposta de uma considerável parte dos intelectuais católicos paraibanos, especialmente os que publicavam no jornal A Imprensa, era inculcar naquele nicho temático o modelo instrucional que propunha o dispositivo da instrução religiosa como mecanismo de sedimentação moral. Este último, se argumentava, não vivenciado naqueles espaços estatais, neste caso, as casas alugadas nas quais funcionavam as cadeiras isoladas. Em tempo: as casas escolares apresentavam tantos problemas que os gestores da instrução pública frequentemente reiteravam a necessidade de mudanças na precária situação das escolas publicas ${ }^{44}$.

Nos anos imediatamente posteriores à fundação da Diocese da Paraíba, a tendência dos discursos foi se tornarem ainda mais empertigados na construção de um sentido moralizante para a escola, e de um discurso para a Igreja, como condutora dos costumes e da formação dos fiéis. Aspecto que não era possivel, segundo argumentavam, na escola pública sem o catolicismo. Somente ela, a Igreja Romana, nunca o Estado republicano poderia sanar tal lacuna. Particularmente com a publicitação de documentos oficiais da Igreja, já supracitados, e devidamente publicados na imprensa como princípio normativo, tal argumento se intensificou. No tocante às interpretações que se seguiram àqueles documentos foi nos textos dos articulistas locais que se apresentou marcante a influência das encíclicas papais $e$ cartas pastorais. A batalha discursiva mundial se tornou também local. Era a instrução confessional, tema privilegiado e recorrente.

Os ímpios se esforçam por todos os dias para deschristianizar o povo e a sociedade, e começando pela base lançam mão de todos os meios para corromper a família e perverter a educação da infância. É necessário, portanto, que os paes de família se esforcem e lutem constantemente para repelir com energia qualquer injustiça nesta matéria até conseguirem plena liberdade para educar christamente os seus filhos $e$ sobretudo prohibir-lhes a frequência a escolas onde haja perigo de que, com o ensino, bebam o veneno da impiedade. Com razão pois, a Egreja catholica, guarda e defensora da integridade da fé condena as escolas neutras, mixtas e leigas em que se suprime todo ensino da doutrina christã. ${ }^{45}$

\footnotetext{
${ }^{43}$ PINHEIRO, Antônio Carlos Ferreira. Da Era das cadeiras isoladas à Era dos grupos escolares na Paraíba. Campinas: Autores Associados; São Paulo: Universidade São Francisco, 2002, p. 35.

${ }^{44}$ PINHEIRO, Da Era..., p. 74.

${ }^{45}$ REPRESENTAÇÃO sobre o ensino. A Imprensa, Cidade da Parahyba, n. 11, 19 mar. 1912.
} 
Os respectivos discursos, na década de 1910, foram condizentes com as reflexões e a militância do laicato católico, lançadas à sociedade brasileira a partir de seus centros, jornais e dioceses. Artigos inflamados no jornal A Imprensa se sucediam, tais como: O destino do homem, de Brasilio Machado que alertava: Que será das escolas sem deus? ${ }^{46}$ e A educação do clérigo, de Pinto dos Santos. No artigo Vejo Christo expulso das escolas, vejo em tudo a educação sem Deus ${ }^{47}$, da autoria de Felizardo Toscano, deputado pela Parahyba do Norte e católico militante, afirmava-se: a escola, pelo aspecto, pelo ensino e pelo exemplo, ensina e deve moralizar ${ }^{48}$. Ao mesmo tempo, é de sua autoria uma série de artigos sobre a instrução leiga, nos quais, como muitos outros, realizava uma análise de temas em que a Igreja devia atuar, ou se tornar viva e copartícipe: o ensino cívico se for ministrado com seriedade dará como resultado a diminuição dos amotinadores ${ }^{49}$.

Também levamos em consideração que foi na mesma seara discursiva da legitimidade da Igreja, perante a sociedade secularizada, particularmente no tocante à instrução, na qual acabou assentada uma série de textos daqueles intelectuais, publicados em A Imprensa entre 1912 e 1919. Podemos inquirir a que grau andava a formação de preceitos críticos, quanto à instrução pública secularizada, em prol de uma cultura confessional de instrução. Em estados como a Parahyba do Norte, tal debate não cessou.

Exatamente pela extensão de temas dispostos à época, manifestava-se a complexidade dos atores sociais envolvidos com a função-guia, à qual se dedicava boa parte dos discursos provindos da catolicidade, aqueles em que estava assentada uma série de estratégias que iam da publicação de obras apologéticas, traduções de textos oficiais, encíclicas e cartas pastorais em seus veículos jornalísticos, assim como todo um cabedal de suportes impressos a afirmarem, como nos aponta Miceli ${ }^{50}$, a proeminência da romanização e da Igreja em assuntos que tocavam a instrução, considerada ferramenta útil entre as estratégias da manifestação de recristianização da sociedade.

Todo um capital simbólico na esfera do que nos afirma Bourdieu ${ }^{51}$, no qual estavam inseridos padres e leigos, fez-se afirmar, diariamente, entre as páginas militantes dos periódicos uma seara de conflito mudo, mas persistente. Não seria estranho, especialmente à Cúria local, certa abertura de espaço nos editoriais de seu principal órgão jornalístico, para a discussão sobre temas comuns à República e à Igreja. Importava tornar públicas as opiniões de seus intelectuais. Outrossim, na esfera da manutenção de privilégios, mesmo estando proibida pela Constituição de 1891, a proeminência daquela instituição nos assuntos estatais é verificável, como revela trecho de artigo - não assinado - de 1913: O que é exequível, emitentemente practico, equitativo e justo é favorecer o governo ao ensino, subvencionando as escolas

\footnotetext{
${ }^{46}$ O DESTINO do homem. A Imprensa, Cidade da Parahyba. n. 14, 5 set. 1912.

${ }^{47}$ A EDUCAÇÃO. A Imprensa, Cidade da Parahyba. n. 17, 12 out. 1912.

${ }^{48}$ DA INSTRUÇÃO. A Imprensa, Cidade da Parahyba, n. 33, 5 dez. 1912.

${ }^{49}$ A SÃ política e a instrucção. A Imprensa, Cidade da Parahyba, n. 29, 21 nov. 1912.

${ }^{50}$ MICELI, A elite eclesiástica..., 2009.

${ }^{51}$ BOURDIEU, Pierre. Economia das trocas simbólicas. Rio de Janeiro: Bertrand Brasil, 2007, p. 15-234.
} 
públicas ou particulares, confessionais ou leigas reservando a si a fiscalização das mesmas no que entende com o programma geral de ensino ${ }^{52}$.

Aparentemente, enquanto eram debatidos, por volta da década de 1910, assuntos de um universo que dialogava com a estrutura pública, cívico-republicana, era na cotidianidade que se revelava a real necessidade de retorno a um estado de coisas, ainda não resolvido: o do monopólio instrucional a partir de matriz cristã $e$ confessional, argumento rotineiro entre os agentes clericais. As subvenções, portanto, eram bem-vindas enquanto instrumentais nas relações burocráticas balizadoras, sempre quando convenientes da relação da Igreja com o Estado. Fariam, à medida que se fizessem presentes, papéis cristalizadores de intensões de uma reconquista em tons de cruzada.

A circulação dos debates intelectuais que postulavam respostas para temas que afligiam as instituições católicas, ao iniciar entre as décadas de 1910 e 1920, foram contínuos a partir da temática da secularização da instrução. Principalmente como resposta às demandadas por escolas que se mantivessem na esfera de influência da Cúria e, na rota contrária, a uma série de mudanças legislativas nos estados da federação. Entre as tais mudanças, a escola neutra e mista.

Contraditoriamente, aqueles discursos foram formulados na possibilidade de legitimar certa adaptabilidade manifestada nas vias de diálogo normativas, $e$ equiparações ao Ginásio Nacional, por exemplo, condições reguladoras $e$ burocráticas que permaneceram a ditar tendências discursivas. Tendências nas quais a instrução era temática recorrente de ajustamento e amortecimento, sobretudo do impacto secular/ profano sobre a sociedade paraibana.

Os discursos pela afirmação de uma espécie de front, nos quais estiveram intelectuais a lutar pela escola confessional ou laica, tornaram-se emblemáticos à medida que novos espaços de formação católicos foram fundados. Afinal, na mesma medida, jornalistas, bacharéis em direito e outros setores militantes se lançaram a defender modelos de desenvolvimento, ou atraso, trazidos por um e outro modelo instrucional, positivista ou teleológico providencialista, secular ou confessional.

Ao mesmo tempo, foi intensa na Parahyba do Norte, nas três primeiras décadas do século $\mathrm{XX}$, a condição de articulistas, lentes e militantes, de muitos agentes clericais ou laicos que se esforçavam por dar uma identidade de engajamento a seus textos, palestras e cartas. Era o caso de religiosos tais como Florentino Barbosa e o cônego Joffily. O primeiro, jornalista do jornal A Imprensa e o segundo diretor do Diocesano Pio X, Florentino Barbosa, inclusive foi importante escritor de uma longa série de artigos alinhados com o Ultramontanismo ${ }^{53}$.

Era notável, da mesma forma, que junto aos colégios diocesanos, uma série de padres na condição de lentes da escola pública, e outros tantos leigos, se apresentassem como articulistas sempre atentos a defenderem, junto aos católicos paraibanos, seus preceitos confessionais.

${ }^{52}$ INSTRUCCÃO Publica. A Imprensa, Cidade da Parahyba, n. 7, 8 set. 1913.

${ }^{53}$ O Ultramontanismo designou forte corrente intelectual católica que postulava uma reação aos preceitos religiosos e discursivos não alinhados com o catolicismo. A saber: maçonaria, liberalismo, protestantismo, espiritismo, entre outras. Entre os principais representantes daquela ala intelectual na Parahyba do Norte estavam os padres, Manuel Paiva, José Thomaz Gomes da Silva e Santino Coutinho, todos envolvidos diretamente com a Cúria e sob as ordens de Dom Adauto. 
Afinal, os mesmos seminaristas, saídos dos bancos do seminário da diocese dominado com mão de ferro por Dom Adauto, acabavam se destacando como intelectuais num verdadeiro exército das letras, a produzirem ou reproduzirem os ditames da militância.

Também era o caso de jornalistas, médicos e bacharéis que escreviam artigos dedicados à instrução. Por volta de 1912, de Tacima, escrevia o jornalista Celso Amâncio Ramalho, sobre a escola pública do estado.

Muito em despendido o nosso caro estado com modelações $e$ remodelações attinentes a melhorar a situação assumida pela instrucção publica, dentro dos liames da pedagogia $e$ methodos modernos. Mas improfícuo tem sido o interesse tomado especialemente nas zonas mais afastadas. Ali o limite da infleuncia do educador, estreito e acanhado pela falta de estimulo, pouco ou quasi nada interessa [...] as creanças geralmente nada aprendem; vão a escola dominadas pelo desejo da vadiacão, da garotada desenfreada que a insensível apparencia de um intruso. ${ }^{54}$

No governo de João Pereira de Castro Pinto (1912-1915), todavia, ocorreu uma espécie de concórdia entre as estratégias republicanas e os interesses da Cúria. Castro Pinto era, a olhos vistos, o governador mais simpático à causa católica, embora tivesse que enfrentar levas de textos a reivindicar uma postura combativa dos católicos paraibanos, quanto à neutralidade na instrução, a saber: a instrução laica. Castro Pinto, diga-se, enquanto intelectual havia defendido o ensino técnico, ao mesmo tempo em que sancionava a defesa da escola católica.

Esta última, não necessariamente uma temática vivenciada nas redações, mas tema recorrente entre os intelectuais-clérigos espalhados pelo estado, tanto na sala de estar de uma família tradicional, onde se discursava contra o universo profano, $e$ onde se alistava o futuro seminarista, quanto no sermão matinal, aquele que arrebanhava os fiéis nas missas dominicais.

Já no nicho intelectual leigo também havia forte estímulo à legitimação da cultura escolar cristã, e o mesmo passava pela defesa da fundação de escolas, ou vivências escolares, que se não eram de escopo plenamente cristocêntrico em sua raiz, por não serem de um núcleo escolar-congregacional, dispunham-se a compactuar com seu formato doutrinário, pelo menos no que tangia à esfera de seus capitais simbólicos: disciplina, moral cristã e doutrinação romanizada. Não era necessariamente apenas da condição de jornalistas ou padres, a publicarem na imprensa, da qual se alimentava a militância católica. De forma contraditória, entre rompantes ultramontanos na Parahyba do Norte, qualquer festa cívica passava ainda pela chancela dupla: 1) de seus protagonistas leigos, muitos, entre eles, a se colocarem a serviço do projeto cristianizador da Igreja; e 2) das autoridades católicas articuladas ao poder local.

${ }^{54}$ A ESCHOLA que se quer moderna ou tradicional? A Imprensa, Cidade da Parahyba, n. 65, 12 set. 1922. 
No período, uma série de instituições particulares na cidade e no resto do estado sempre se apresentava como detentora do ensino religioso como parte de suas respectivas grades curriculares. Seus diretores e professores - não era coincidência também acabavam como articulistas nos jornais do estado ou nos espaços destinados aos seus ofícios.

Pelo interior, educadoras formadas na Escola Normal da capital mantinham internatos, tais como a professora Julia Leal, importante educadora da cidade de Areia. A seu respeito, remonta uma considerável quantidade de notas e artigos alusivos a seus esforços, enquanto professora $e$ intelectual, por uma instrução de matriz confessional.

Ha mais de duas décadas, a exma snr. d.Julia Verônica dos Santos Leal fundou na cidade de Areia um curso-internato, semi-internato e externato - que tem presyado à instrucção os mais assignalados serviços. Padres. médicos, bacharéis, adeantados comerciantes, professores normaes - já diversos se contam antigos alunos de d.Julia no seu bem organizado estabelecimento. ${ }^{55}$

Era marcante o suporte simbólico dado pela Igreja, fosse pelo discurso de valorização dos intelectuais católicos, fosse pelo fomento no sentido de reforçar a presença daqueles lentes junto aos colégios, fundados tantas vezes por ex-estudantes do Seminário Diocesano ou ex-normalistas.

Afinal, enquanto diretores ou lentes ministravam o ensino de história pátria na mesma medida em que ensinavam sobre os heróis da bíblia, no qual o civismo se transmutava, pelas mãos dos mesmos intelectuais, a festejar a ressignificação dos símbolos da República: de culto nacional em religião civil, a sacralizar os símbolos da pátria. Entre o ensino de química, física e biologia continuava incrustada nos espaços escolares a iniciativa da história sagrada e do ensino religioso. As fronteiras nem sempre respeitadas, quer em espaço público ou privado.

$\mathrm{Na}$ Parahyba do Norte, como em outros estados da federação, muitas vezes era cultuada a figura histórica de Tiradentes, como personagem-mártir da República, à medida que eram cantadas ladainhas nas inaugurações de grupos escolares estaduais ${ }^{56}$. Marchava-se em honra ao sete de setembro e se concorria à primeira comunhão, nos espaços públicos de instrução ${ }^{57}$. Na mesma condição, cursos $e$ cadeiras isoladas que pudessem dar vasão ao já especificado projeto romano, em suas mais diversas tramas, foram espalhados pelo estado. Exemplo maior foi a manutenção de cadeiras que funcionavam subvencionadas pelo estado, embora estivessem sob a tutela de ordens e congregações religiosas ${ }^{58}$, manifestação prática de propostas e discursos anteriores.

${ }^{55}$ CURSO Julia Leal. A Imprensa, Cidade da Parahyba, n. 93, 24 ago. 1923.

${ }^{56}$ TIRADENTES: Festa cívica no Colégio Nossa Senhora das Neves. A União, Cidade da Parahyba, n. 13, 21 abr. 1922.

${ }^{57}$ FESTA religiosa no colégio normal: celebrando a primeira comunhão. A União, Cidade da Parahyba, n. 13, 03 mai. 1922.

${ }^{58}$ QUADRO demonstrativo da receita: subvenções. A União, Cidade da Parahyba, n. 13, 21 abr. 1922. 
$\mathrm{Na}$ capital, escolas como, por exemplo, a São José, funcionavam nas dependências da Igreja Nossa Senhora de Lourdes, assim como apresenta a nota de A Imprensa, publicada a 3 de março de $1920^{59}$. Embora constasse aquela iniciativa como cadeira isolada, fiscalizada e mantida pelo Estado, era administrada por religiosos. Portanto, funcionava na esfera de influência direta de Dom Adauto.

Da mesma forma, os discursos que inferiam a benemerência na administração de orfanatos-escola, especialmente a partir de uma prática coparticipe entre Estado $e$ Igreja, acabaram finalmente como uma ferramenta de arrebanhamento de fiéis, $e$ mais um lugar de representação da querela mantida desde a fundação da Diocese. Em espaços tais como o do Orfanato Dom Ulrico, estavam os discursos médicos, higienistas e secularizantes no mesmo patamar da confessionalidade.

Certamente a secularização social havia avançado, mesmo ali entre padres do Liceu paraibano, jornalistas republicanos, ou sócios da principal associação positivista local, o Instituto Histórico e Geográfico Paraibano (IHGP), fundado em 1905.

Podemos apontar como ponto de inflexão, que se transformou em guerra aberta, entre os setores intelectuais católicos e laicos, sem espaço para maiores diálogos, o advento de uma arregimentação jornalística disposta com a fundação em 1922 do Centro Dom Vital. Este centro intelectual, baseado no Rio de Janeiro, capitaneado por intelectuais como Carlos de Laet e Jakson de Figueiredo, projetou e potencializou as alas endurecidas do catolicismo que passaram a projetar um modelo aguerrido para os princípios teológicos, sociais, políticos e instrucionais dos anos 1920. Certamente houve uma diminuição nos discursos hibridizantes em detrimento da ortodoxia.

A partir de 1922 as instruções aos católicos, que partiam do Centro Dom Vital, tornado uma espécie de órgão representante do arcebispado e do laicato brasileiro, eram encaminhadas para todo o país como regra: guerra sem quartel à laicização da instrução. Daí, publicações, imediatamente impactantes sobre o cotidiano católico, se espraiarem na redação de A Imprensa, com a bênção de Dom Adauto, intelectuais alinhados com Roma, professores e jornalistas.

A revista $A$ Ordem aparecia resenhada a cada número apresentado no periódico da Cúria. Elogios públicos às escolas cristãs, que se apresentavam recorrentes, passaram a ser publicados semanalmente dentro de um formato combativo que emanava do Rio de Janeiro. Também a partir de minibiografias, publicação de artigos e plaquetas alusivas aos intelectuais católicos, foi reforçada a necessidade de empenho da comunidade paraibana.

Mesmo assim, de forma contraditória, representativa da maneira como a secularização em sua forma adaptativa se apresentava no Brasil, e na Parahyba do Norte, podemos destacar o artigo: No seminário: a comemoração do centenário, publicado nas páginas de A Imprensa em 7 de setembro de 1922, por ocasião da comemoração alusiva ao centenário da independência do Brasil:

No domingo passado a directoria do velho educandário onde se formam os sacerdotes do clero parahybano promoveu significativa sessão literária em homenagem ao primeiro

\footnotetext{
${ }^{59}$ ESCOLAS parochiais. A Imprensa, Cidade da Parahyba, n. 10, 08 mai. 1922. 
centenário de nossa emancipação politica. Presidiu-a o excelentíssimo Senhor arcebispo metropolitano ladeado pelo excelentíssimo monsenhor João Milanez representando o sr. Dr. presidente do Estado... nos intervalos foram cantados pelos alunos os hymnos nacional, da independência, da Parahyba, da bandeira e do centenário acompanhados a piano pelo padre José Coutinho. Finalmente o senhor arcebispo pronunciou as seguintes palauras muito significativas e apropriadas ao momento: caríssimos filhos, que vos hei de dizer mais? Meus parabéns. Deus e pátria! Viva o Brasil! ${ }^{60}$

Àquela altura somava-se ao intuito cívico, que se arvorava nos espaços clericais paraibanos, tais como o Seminário Diocesano, uma arguta dinâmica de que embora fossem rivais nos trâmites do sistema instrucional, Estado e Igreja, respectivamente, completavam-se na necessidade de comungarem de símbolos em comum. Em que pesem as querelas diárias $e$ as estratégias de monopólio social e cultural, por parte de ambos os contendores, era na possibilidade de tornar a instrução ferramenta de combate, em que se assentavam os fronts.

Enfim, anos depois, nos anos 1930, tanto os arrefecimentos discursivos quanto os trâmites híbridos retomaram a carga, em grau de intensidade, no tocante ao formato pertinente à instrução, notadamente junto à constituinte de 1933. Logo, em 1934, era sancionada uma carta e um projeto vencedor de Estado que se permitia cristão. Embora propagasse a ideia de teor facultativo do ensino religioso, claramente optava por um escopo católico.

Os protagonistas eram outros, porém, permaneceria o cerne dos debates inaugurados com a fundação da diocese paraibana, com a abertura da frente legitimista do Centro Dom Vital, e junto à circulação das ideias da Igreja romanizada, em periódicos como A Imprensa. Já eram maduros os padres, jornalistas e bacharéis formados nos círculos do catolicismo engajado paraibano. As querelas seriam reajustadas.

\section{$\operatorname{son}$}

${ }^{60}$ NO SEMINÁRIO: a comemoração do centenário. A Imprensa, Cidade da Parahyba, n. 12, 7 set. 1922. 


\section{RESUMO}

A construção de militâncias intelectuais, especialmente as que se apresentavam a partir de novos significados discursivos para a escola contemporânea, se deu a partir de disputas fomentadas na transição dos séculos XIX e XX. Nesse sentido, todo um cabedal de protagonismos do qual a Igreja católica se ressentia, estava assentado em verdadeira guerra de modelos instrucionais. No âmbito de uma maior presença da secularização social $e$ cultural, se fez apresentar como instrumental de afirmação da Igreja, a temática da escola confessional. Em muitas dioceses espalhadas pelo mundo, encíclicas papais, lançavam propostas educacionais nas quais instituições católicas eram apontadas como solução para um mundo cada caracterizado como indiferente, mundano e laico. Nosso artigo, partindo da leitura do periódico diocesano A Imprensa, discute a representação das querelas textuais a partir dos conceitos de Nestor Garcia Canclini, sobre hibridismo cultural. Para tanto, lançamos mão da análise dos postulados elaborados pelos articulistas locais, tanto no tocante ao universo escolar confessional, quanto dos intelectuais secularistas. Estes últimos a partir de Fernando Catroga, que identifica-os enquanto intelectuais que defendem os signos da religião civil, nos regimes republicanos.

Palavras Chave: Catolicismo; Instrução Confessional; Secularização.
ABSTRACT

The construction of intellectual militants, especially those that presented themselves from new discursive meanings for the contemporary school, took place from disputes fomented in the transition of centuries XIX and XX. In this sense, a whole range of protagonisms that the Catholic Church resented was based on a true war of instructional models.In the context of a greater presence of social and cultural secularization, the theme of the confessional school was presented as an instrument of affirmation of the Church. In many dioceses scattered throughout the world, papal encyclicals launched educational proposals in which Catholic institutions were pointed out as a solution to a world characterized as indifferent, worldly and secular. Our article, starting from the reading of the diocesan newspaper A Imprensa, discusses the representation of the textual quarrels from the concepts of Nestor Garcia Canclini, on cultural hybridism. In order to do so, we have analyzed the postulates elaborated by local Catholic writers, both in regard to the confessional school universe and the secularist intellectuals. The latter from Fernando Catroga, who identifies them as intellectuals who defend the signs of civil religion in the republican regimes.

Keywords: Catholicism; Confessional Instruction; Secularization.

Artigo recebido em 22 mar. 2016.

Aprovado para publicação, após alterações solicitadas pelos pareceristas, em 13 fev. 2017. 